\title{
Quality characteristics and antioxidant activities of rice crispy cereal added with Enteromorpha prolifera
}

\author{
Da Hee Kim, Seung Yeon Baek, Mee Ree Kim* \\ Department of Food and Nutrition, Chungnam National University, Daejeon 34134, Korea \\ 가시파래 첨가 크리스피 쌀과자의 품질 특성 및 항산화 활성 \\ 김다희 · 백승연 · 김미리* \\ 충남대학교 식품영양학과
}

\begin{abstract}
In this study, 1, 3, and 5\% of Enteromorpha prolifera ( $E$. prolifera, green laver) powder was added to the rice crispy cereal, a gluten-free food. The quality characteristics and antioxidant activities of rice crispy cereal were investigated. The reducing sugar content decreased with increased contents of $\boldsymbol{E}$. prolifera powder. In the Hunter color system, the $L$ and a values decreased, while the $b$ values increased with increasing $E$. prolifera content. The phycocyanin and chlorophyll contents (antioxidant pigments) increased with increasing amounts of $E$. prolifera. The $5 \%$ E. prolifera additive group exhibited the maximum antioxidant and radical (DPPH and hydroxyl) scavenging activities. The flavonoid and total phenolic contents were also the maximum in this group. The intensity test results revealed that rice crispy cereal containing $5 \%$ E. prolifera exhibited the highest overall acceptability. Based on these results, The study presents the preliminary data that can be used to improve the nutritional value of rice crispy cereal. The results revealed that powdered $E$. prolifera can be added in different proportions to various types of food for the development of different food items having varying properties.
\end{abstract}

Key words : Enteromorpha prolifera, rice crispy cereal, quality characteristics, antioxidant activities

서 론

쌀은 우리나라 식량작물의 $85 \%$ 를 차지할 정도로 농업에 서 큰 비중을 차지하고 있지만, 해가 거듭할수록 쌀의 소비량 은 감소하는 추세이다. 2018년 양곡소비량조사 결과, 2018년 1 인당 쌀 소비량은 $61.0 \mathrm{~kg}$ 으로 전년대비 $1.3 \%(0.8 \mathrm{~kg})$ 감소한 반면, 제조업부문(식료품 및 음료)의 쌀 소비량은 75 만 5,664 톤으로 전년대비 $6.8 \%(4$ 만 7,961 톤) 증가하였다(KOSIS, 2018). 즉, 쌀을 주식으로 섭취하는 비율은 감소한 반면, 쌀을 가공식품 형태로 섭취하는 비율은 증가하고 있어, 제조업에
서의 쌀 이용이 중요해 보인다. 쌀은 알레르기 위험성이 적 고, 영양소가 풍부하여 밀가루 대체 식품으로도 적절하다 (Tie 등, 2012). 소비자가 더욱 개발되길 원하는 쌀 가공식품 은 면류 $24.4 \%$, 빵류 $24.0 \%$ 에 이어 과자류가 $19.3 \%$ 로 높은 편이다(Guk과 Han, 2010).

곡류는 고온고압에 의해 팽화되면 수분의 증발로 건조해 지고, 호화 및 성분 변화로 인해 조직감 특성이 개선된다. 곡 류를 팽화시킨 대표 식품인 시리얼은 바삭한 특성을 가진다 (Tie 등, 2012). 이를 활용한 가공식품으로는 아침식사 대용 식으로 각광 받는 스낵바인 크리스피가 있다. 이는 쌀로 제조

\footnotetext{
*Corresponding author. E-mail : mrkim@cnu.ac.kr, Phone : +82-42-821-6837, Fax : +82-42-821-8671

Received 4 August 2020; Revised 13 October 2020; Accepted 22 October 2020.

Copyright (c) The Korean Society of Food Preservation.

This is an Open Access article distributed under the terms of the Creative Commons Attribution Non-Commercial License (http://creativecommons.org/licenses/by-nc/4.0) which permits unrestricted non-commercial use, distribution, and reproduction in any medium, provided the original work is properly cited.
} 
하기도 하고, 영양소가 풍부한 기능성 식품 소재를 부재료로 첨가하여 영양바로도 불린다(Han 등, 2005). 기능성 식품 소재 를 가한 곡류 영양바로는 감귤 농축액 영양바(Park 등, 2014), 아로니아 쌀 영양바(Rye 등, 2015), 뽕잎 쌀 영양바(Lee, 2019), 양배추 쌀 영양바(Joo와 Choi, 2016) 등이 있다. 하지 만 현재까지 기능성 식품 소재를 첨가한 영양바 연구는 그 수가 적으며, 부재료는 대개 과일이나 야채이고, 해조류를 첨 가한 영양바는 없는 실정이다.

가시파래는 동아시아 해안과 우리나라 서해안 일부지역에 서 2 월에서 3 월 사이 추운 겨울에 생산되는 갈파래과 다년생 해조류이다. 청정해역에서만 서식하며 자라는 특성 등 성장 조건이 까다로워 서해안에서도 일부지역에서만 소량 생산된 다. 생김새는 김과 비슷하며, 머리털 같이 가느다라며 푸른 색을 띄는 것이 특징이다. 파래, 매생이와 비슷한 초록색이 지만 파래보다는 가닥이 가늘고 매생이보다는 두꺼우며 씹 는 식감이 좋고 특유의 진한 향이 난다(Kim 등, 2019a). 가시 파래의 초록색은 산화방지와 관련된 클로로필 색소 성분이 며, 항산화성, 항염증, 신경세포 보호에 도움을 주는 피코시 아닌 색소와 카로티노이드를 함유하고 있다(Baek과 Kim, 2019). 가시파래는 다른 해조류에 비해 리놀레산(linoleic acid), 리놀렌산(linolenic acid) 등의 필수 지방산 함량과 단 백질, 수용성 탄수화물, 섬유질 함량이 높으며 $(\mathrm{Li}$ 등, 2010), 칼륨, 칼슘, 철, 망간, 구리 등의 풍부한 무기질을 가진 고단 백, 저지방 해조류의 일종이다(Liao 등, 2011). 해조류는 황 산 다당류의 가장 중요한 공급원으로, 많은 연구에서 가시파 래의 황산 다당류가 강력한 항산화제로 밝혀졌다 $(\mathrm{Li}$ 등, 2013). 이는 당뇨예방(Lin 등, 2015), 면역 예방(Mao 등, 2008) 등 다양한 약리작용에 효과가 밝혀지면서 기능성 식품으로 써 활용 가치가 높아지고 있다. 가시파래는 생리활성 효과에 대한 연구 이외에도 가시파래 항산화 물질의 추출방법 및 그 추출물을 이용한 식품의 제조방법, 정제와 과립제에 대한 연 구들이 보고되었다.

최근 소비자들의 건강과 식품에 대한 관심 증가로 건강식 품에 대한 소비가 높아졌는데, 해조류는 다양한 생리활성물 질을 함유하여 건강식품으로써 그 가치와 인식이 높고, 많은 연구가 진행되고 있다(Lee, 2013). 그러나 가시파래는 김과 같이 대중화된 식재료가 아니기에 현재는 성분 연구에 초점 이 맞춰져 있으며, 최근 들어 가시파래를 첨가한 식품에 대한 연구가 진행 중이다. 따라서 가시파래를 식품에 첨가하여 건 강에 도움을 줄 수 있는 연구를 진행해보려고 한다.

본 연구에서는 가시파래를 활용하고자 쌀을 호화시킨 시 리얼로 제조한 크리스피 쌀과자에 가시파래를 첨가하여 식품 을 제조하였고, 그 특성을 알아보고자 품질 특성과 항산화성 을 측정하였다.

\section{재료 및 방법}

\section{실험재료}

본 실험에 사용된 가시파래 분말(Songwon Foods Co., Ltd., Seosan, Korea)은 $-70^{\circ} \mathrm{C}$ deep freezer(Ultra-Low Temperature Freezer, SW-UF-400P, Samwon Freezing Engineering Co., Busan, Korea)에 보관한 것을 사용하였고, 그 외에 puffed rice (Kellogg Co., Ltd., Battle Creek, MI, USA), 마시멜로 우(Doumak Inc., Elk Grove Village, IL, USA), 버터(Lotte Foods Co., Ltd., Cheonan, Korea)를 사용하여 제조하였다.

\section{크리스피 쌀과자 제조}

크리스피 쌀과자에 첨가하는 가시파래 함량은 예비 실험 및 관능검사를 통해 적절하다고 판단된 양으로 정하였으며, 이는 puffed rice $100 \mathrm{~g}$ 을 기준으로 $1 \%, 3 \%, 5 \%$ 를 첨가하여 제조하였다. 크리스피 쌀과자의 재료 및 분량은 Table 1과 같 다. 제조법은 팬에 버터를 녹인 후 마시멜로우를 넣고 누르며 겉면만 살짝 녹여주었다. 이 때 가시파래를 넣고 색이 고르게 되도록 섞어주다가 puffed rice를 넣고 잘 섞어주었다. 완성 된 것을 틀에 넣어 모양을 형성하고 1 시간 식혀준 뒤, 실험에 사용하였다.

\section{환원당 함량 분석}

환원당은 시료 $5 \mathrm{~g}$ 에 증류수 $45 \mathrm{~mL}$ 를 균질화한 것을 $40^{\circ} \mathrm{C}$ 의 sonication(Powersonic 420, Hwashin Tech Co., Ltd., Busan, Korea)에서 20 분동안 반응시킨 후, $3,000 \mathrm{rpm}, 4^{\circ} \mathrm{C}$ 로 설정된 원심분리기(Centrifuge, Combi-514R, Hanil Science Co., Ltd., Hwaseong, Korea)로 20분동안 원심분리하였다. 여과하여 얻어진 상징액을 dinitrosalicylic acid(DNS)에 의한 비색법으로 $550 \mathrm{~nm}$ 의 분광광도계(UV-1800, BioTeck Instruments Inc., Winooski, VT, USA)로 흡광도를 측정하여

Table 1. Recipe of rice crispy cereal added with Enteromorpha prolifera

\begin{tabular}{crrrc}
\hline Ingredient (g) & Control $^{1)}$ & EPC $^{2)}$ & EPC 3 & EPC 5 \\
\hline Butter & 30 & 30 & 30 & 30 \\
Marshmallow & 150 & 150 & 150 & 150 \\
Puffed rice & 100 & 99 & 97 & 95 \\
E. prolifera powder & 0 & 1 & 3 & 5 \\
\hline Total & 280 & 280 & 280 & 280 \\
\hline
\end{tabular}

${ }^{1)}$ Control, rice crispy cereal without $E$. prolifera; EPC $1,1 \%$ E. prolifera rice crispy cereal; EPC $3,3 \%$ E. prolifera rice crispy cereal; EPC $5,5 \%$ E. prolifera rice crispy cereal.

${ }^{2)} \mathrm{EPC}$, Enteromorpha prolifera rice crispy cereal. 
포도당(glucose) 함량으로 나타내었다. 표준곡선은 농도별로 반응시킨 포도당(Sigma-Aldrich Co., St. Louis, MO, USA) 의 흡광도 값으로 작성하였다.

\section{색도 측정}

시료는 $15 \mathrm{~g}$ 씩 동일한 크기와 모양으로 잘라 페트리디쉬 $(50 \times 12 \mathrm{~mm})$ 에 놓고 Hunter 색차계(ND-1001 DP, Nippon Denshoku Co., Ltd., Tokyo, Japan)로 L값(lightness), a값 (redness), b값(yellowness)을 반복 측정하여 나타내었다. 표 준 백색은 L값 $99.35, \mathrm{a}$ 값 $-0.14, \mathrm{~b}$ 값 -0.36 을 사용하였다.

\section{피코시아닌 및 클로로필 함량 측정}

피코시아닌은 시료 $3 \mathrm{~g}$ 과 $80 \%$ 메탄올 $27 \mathrm{~g}$ 을 균질화한 후, $40^{\circ} \mathrm{C}$ 의 sonication(Powersonic 420 , Hwashin Tech Co., Ltd.)에서 2 시간 동안 반응시킨 것을 $3,000 \mathrm{rpm}, 4^{\circ} \mathrm{C}$ 로 설정 된 원심분리기(Combi-514R, Hanil Science Co., Ltd.)로 20 분 동안 원심분리하였다. 여과하여 얻어진 상징액을 $620 \mathrm{~nm}$, $652 \mathrm{~nm}$ 의 분광광도계(UV-1800, BioTeck Instruments Inc.) 로 흡광도를 측정한 후 아래의 식에 대입하여 피코시아닌 함 량을 크리스피 $1 \mathrm{~g}$ 당 $\mu \mathrm{g}$ 으로 나타내었다(Shim 등, 2010).

C-Phycocyanin ( $\mu \mathrm{g} / \mathrm{g}$ of crispy)

Allophycocyanin $(\mu \mathrm{g} / \mathrm{g}$ of crispy)

$$
=\left[\mathrm{A}_{620}-0.474\left(\mathrm{~A}_{652}\right)\right] / 5.34 \times 1000
$$

$$
=\left[\mathrm{A}_{652}-0.208\left(\mathrm{~A}_{620}\right)\right] / 5.09 \times 1000
$$

클로로필은 시료 $1 \mathrm{~g}$ 과 DMSO $20 \mathrm{~g}$ 을 균질화한 후, $40^{\circ} \mathrm{C}$ 의 sonication(Powersonic 420, Hwashin Tech Co., Ltd.)에서 24 시간 동안 반응시킨 것을 $3,000 \mathrm{rpm}, 20^{\circ} \mathrm{C}$ 로 설정된 원심 분리기(Combi-514R, Hanil Science Co., Ltd.)로 20분 동안 원심분리하였다. 여과하여 얻어진 상징액을 $664 \mathrm{~nm}, 648 \mathrm{~nm}$ 의 분광광도계(UV-1800, BioTeck Instruments Inc.)로 흡광 도를 측정한 후 아래의 식에 대입하여 클로로필 함량을 크리 스피 $1 \mathrm{~g}$ 당 $\mu \mathrm{g}$ 으로 나타내었다(AOAC, 1990).

Chlorophyll a ( $\mu \mathrm{g} / \mathrm{g}$ of crispy)

$$
=\left[12.25\left(\mathrm{~A}_{664}\right)-2.79\left(\mathrm{~A}_{648}\right)\right]
$$

Chlorophyll b ( $\mu \mathrm{g} / \mathrm{g}$ of crispy)

$$
=\left[21.5\left(\mathrm{~A}_{648}\right)-5.1\left(\mathrm{~A}_{664}\right)\right]
$$

\section{플라보노이드 함량 측정}

시료 $3 \mathrm{~g}$ 과 $100 \%$ 메탄올 $50 \mathrm{~mL}$ 를 $40^{\circ} \mathrm{C}$ 의 sonication (Powersonic 420, Hwashin Tech Co., Ltd.)에서 4시간 동안 교반하고 24 시간 동안 추출한 후, $3,000 \mathrm{rpm}, 4^{\circ} \mathrm{C}$ 로 설정된 원심분리기(Combi-514R, Hanil Science Co., Ltd.)로 20분
동안 원심분리하고, 여과하여 얻어진 상징액을 evaporator (Whatman, Buckinghamshire, UK)로 감압 농축하여 추출물 만 얻었다. 추출물 $200 \mathrm{mg}$ 에 $100 \%$ 메탄올 $1 \mathrm{~mL}$ 를 넣어 200 $\mathrm{mg} / \mathrm{mL}$ 농도로 제조한 추출물 용액을 시료 용액으로 사용하 였다.

플라보노이드는 Davis(Davis, 1947)법을 사용하였다. 시료 용액 $100 \mu \mathrm{L}$ 에 $90 \%$ diethylene glycon $900 \mu \mathrm{L}$ 와 $1 \mathrm{~N} \mathrm{NaOH}$ $20 \mu \mathrm{L}$ 를 넣고 $37^{\circ} \mathrm{C}$ 에서 1 시간 동안 반응시킨 후, $420 \mathrm{~nm}$ 의 분광광도계(UV-1800, BioTeck Instruments Inc.)로 흡광도를 측정하였다. 표준곡선은 농도별로 반응시킨 포화 naringin (Sigma Aldrich Co., St. Louis, MO, USA)의 흡광도 값으로 나타내었고, 플라보노이드 함량은 크리스피 $1 \mathrm{~g}$ 당 $\mathrm{mg}$ naringin equivalent (NAE)로 나타내었다.

\section{총페놀성 화합물 함량 측정}

총페놀성 화합물은 알칼리 상태에서 노란색을 가지는 Folin-Ciocalteu's phenol 시약을 환원시켜 몰리브덴 청색으 로 변화시키는 원리로 측정하였다(Singleton 등, 1999). 알칼 리 상태를 위해 $\mathrm{Na}_{2} \mathrm{CO}_{3}$ 용액을 가해주었다. 시료 용액은 플 라보노이드 함량 실험에서 제조한 것을 사용하였다. 시료 용 액 $50 \mu \mathrm{L}$ 에 증류수 $50 \mu \mathrm{L}$ 와 Folin-Ciocalteu's phenol 시약 $500 \mu \mathrm{L}$ 를 넣고 5 분 동안 반응시킨 후에 $7.5 \% \mathrm{Na}_{2} \mathrm{CO}_{3} 300$ $\mu \mathrm{L}$ 를 넣고 호일로 덮어 30 분 동안 반응시킨 것을 $760 \mathrm{~nm}$ 의 분광광도계(UV-1800, BioTeck Instruments Inc.)로 흡광도를 측정하였다. 표준곡선은 농도별로 반응시킨 포화 tannic acid(Yakuri Pure Chemicals Co., Ltd., Kyoto, Japan)의 흡광 도 값으로 나타내었고, 총페놀성 화합물 함량은 크리스피 1 $\mathrm{g}$ 당 $\mathrm{mg}$ tannic acid equivalent(TAE)로 나타내었다.

\section{$\mathrm{DPPH}$ 라디칼 소거능 측정}

1,1-Diphenyl-2-picrylhydrazyl(DPPH) 라디칼 소거능은 $\mathrm{DPPH}$ 의 자유 라디칼이 항산화 물질의 $-\mathrm{OH}$ 기에 의해 환원 되어 노란색으로 탈색 변화가 일어난 정도로 항산화능의 척 도를 측정하는 실험이다(Blois, 1958). 시료 용액은 플라보노 이드 함량 실험에서 제조한 것을 사용하였다. 농도별로 희석 한 시료 용액 $50 \mu \mathrm{L}$ 에 $1.5 \times 10^{-4} \mathrm{mM} \mathrm{DPPH}$ 용액 $150 \mu \mathrm{L}$ 를 넣고 호일로 감싸 30 분 동안 반응시키고, $515 \mathrm{~nm}$ 의 분광광 도계(UV-1800, BioTeck Instruments Inc.)로 흡광도를 측정 하였다. 아래의 식으로 계산하여 각 농도 별 $\mathrm{DPPH}$ 라디칼 소거능(\%) 검량선을 그린 후, $\mathrm{DPPH}$ 라디칼 소거능이 $50 \%$ 가 되는 농도인 $\mathrm{IC}_{50}$ 값을 구하였다(Goldstein 등, 1979).

Free radical scavenging activity (\%)

$$
=\frac{\mathrm{Abs}_{\text {control }}-\mathrm{Abs}_{\text {sample }}}{\mathrm{Abs}_{\text {control }}} \times 100
$$




\section{Hydroxyl 라디칼 소거능 측정}

시료 용액은 플라보노이드 함량 실험에서 제조한 것을 사 용하였다. 농도별로 희석한 시료 용액 $25 \mu \mathrm{L}$ 에 buffer $50 \mu \mathrm{L}$ 와 $30 \mathrm{mM}$ deoxyribose, $1 \mathrm{mM}$ ascorbic acid, $1 \mathrm{mM}$ EDTA, $1 \mathrm{mM} \mathrm{FeCl}_{3}, 1 \mathrm{mM} \mathrm{H}_{2} \mathrm{O}_{2}$ 용액를 각각 $15 \mu \mathrm{L}$ 씩 넣고 $37^{\circ} \mathrm{C}$ 에 서 1시간 동안 반응시켰다. 그 후 $2 \%$ trichloroacetic acid (TCA) 용액 $50 \mu \mathrm{L}$ 와 1\% thiobarbituric acid (TBA) 용액 50 $\mu \mathrm{L}$ 를 넣고 $100^{\circ} \mathrm{C}$ 에서 20 분간 반응시킨 후 냉각한 뒤 3,000 $\mathrm{rpm}, 4^{\circ} \mathrm{C}$ 로 설정된 원심분리기(Combi-514R, Hanil Science Co., Ltd.)로 20 분동안 원심분리하고 얻어진 상징액을 532 $\mathrm{nm}$ 의 분광광도계(UV-1800, BioTeck Instruments Inc.)로 흡 광도를 측정하였다. 아래의 식으로 계산하여 각 농도 별 hydroxyl 라디칼 소거능(\%) 검량선을 그린 후, hydroxyl 라 디칼 소거능이 $50 \%$ 가 되는 농도인 $\mathrm{IC}_{50}$ 값을 구하였다.

Free radical scavenging activity (\%)

$$
=\frac{\mathrm{Abs}_{\text {control }}-\mathrm{Abs}_{\text {sample }}}{\mathrm{Abs}_{\text {control }}} \times 100
$$

\section{관능 검사}

가시파래 첨가 크리스피 쌀과자의 관능평가는 강도특성으 로 평가하였다(충남대학교 생명윤리위원회 생명윤리 면제심 의 윤리면제 승인번호: 201811-SB-187-01). 관능평가의 패널 은 충분한 훈련과 관능검사 경험이 있는 충남대학교 식품영 양학과 대학생과 대학원생 8 명으로 선정한 후, 7점 척도법으 로 강도평가(1점: 매우 약함, 7점: 매우 강함)를 하였다. 강도 검사 평가 항목으로는 외관 색(exterior color), 비린향(fishy smell), 가시파래 향(flavor of E. prolifea), 가시파래 맛(taste of E. prolifea), 시료에 대한 전체적인 조화를 나타내는 전반 적인 수용도(overall acceptability)에 대하여 평가하였다. 시료 는 동일한 크기와 모양으로 자른 것을 세 자리 난수표가 붙여 진 일회용 접시에 담아 제시해 주었고, 각각의 시료 평가에 미
치는 영향을 줄이고자 따뜻한 물과 함께 제공하였다.

\section{통계처리}

본 실험 결과는 모든 실험을 3 회 이상 반복 측정하여 나온 값을 SPSS 24.0(Statistical Package for Social Science, IBM Corp., Armonk, NY, USA) 프로그램을 통해 기술통계로 평 균 \pm 표준편차를 구하고, 분산분석(ANOVA)을 실시하여 유의성 이 있을 시 Duncan의 다중범위검정(Duncan's multiple range test)을 이용하여 시료 간의 유의차를 검정하였다 $(\mathrm{p}<0.05)$.

\section{결과 및 고찰}

\section{환원당 함량}

가시파래 첨가 크리스피 쌀과자의 환원당 결과는 Table 2 와 같다. 환원당은 대조군, 가시파래 $1 \%$ 첨가군, $3 \%$ 첨가군, $5 \%$ 첨가군이 각각 $2.10 \%, 1.90 \%, 1.87 \%, 1.61 \%$ 로 가시파래 첨가량에 따라 값이 유의적으로 감소하였고 $(\mathrm{p}<0.05)$, 이러한 경향은 가시파래 모닝빵(Kim 등, 2019b)과 가시파래 곤약젤 리(Kim 등, 2019c)와 같다. 가시파래의 구성 단당류는 람노 스(rhamnose, $70.2 \%$ )가 주이며, 그 외에도 포도당(glucose, $26.3 \%$ )과 자일로스(xylose, $3.5 \%$ )가 보고되어 환원당이 검출 된 것으로 사료된다(Kim 등, 2016). 또한, 재료로 사용된 puffed rice는 설탕이 $4 \%$ 로 높은데, 가열 시 열에 의해 설탕 이 단당류로 분해됨에 따라 환원당 함량이 매우 높아지는 것 으로 사료된다(Aida 등, 2007). 시료 제조 시, 가시파래를 첨 가해주는 양만큼 puffed rice 양을 줄여주었기 때문에, 환원 당 함량이 감소되는 것으로 사료된다. 가시파래는 혈당 감소 기능(Lin 등, 2019)을 가지고 있으므로 가시파래 크리스피 쌀 과자는 혈당 조절이 필요한 소비자들을 위한 식사 대용식으 로 활용될 수 있을 것으로 보인다.

\section{색도}

가시파래 첨가 크리스피 쌀과자의 색도 결과는 Table 2 와

Table 2. Reducing sugar content and color value of rice crispy cereal added with Enteromorpha prolifera

\begin{tabular}{|c|c|c|c|c|c|}
\hline & & Control $^{1)}$ & $\mathrm{EPC}^{2)} 1$ & EPC 3 & EPC 5 \\
\hline \multicolumn{2}{|c|}{ Reducing sugar content (\%) } & $2.10 \pm 0.01^{\mathrm{a} 3)}$ & $1.90 \pm 0.01^{\mathrm{b}}$ & $1.87 \pm 0.00^{\mathrm{c}}$ & $1.61 \pm 0.02^{\mathrm{d}}$ \\
\hline \multirow{3}{*}{ Color value } & $\mathrm{L}$ & $77.5 \pm 0.1^{\mathrm{a}}$ & $67.9 \pm 0.02^{\mathrm{b}}$ & $62.7 \pm 0.01^{\mathrm{c}}$ & $58.1 \pm 0.00^{\mathrm{d}}$ \\
\hline & $\mathrm{a}$ & $3.35 \pm 0.02^{\mathrm{a}}$ & $0.19 \pm 0.02^{\mathrm{b}}$ & $-2.36 \pm 0.02^{\mathrm{c}}$ & $-3.69 \pm 0.01^{\mathrm{d}}$ \\
\hline & $\mathrm{b}$ & $19.3 \pm 0.10^{\mathrm{d}}$ & $20.9 \pm 0.06^{\mathrm{c}}$ & $21.4 \pm 0.03^{b}$ & $22.1 \pm 0.02^{\mathrm{a}}$ \\
\hline
\end{tabular}

1)Control, rice crispy cereal without E. prolifera; EPC 1, $1 \%$ E. prolifera rice crispy cereal; EPC 3, 3\% E. prolifera rice crispy cereal; EPC 5 , $5 \%$ E. prolifera rice crispy cereal.

${ }^{2)} \mathrm{EPC}$, Enteromorpha prolifera rice crispy cereal.

${ }^{3)} \mathrm{Mean} \pm \operatorname{SD}(\mathrm{n}=3)$ within each row followed by different letters $\left({ }^{\mathrm{a}-\mathrm{d}}\right)$ are significantly different $(\mathrm{p}<0.05)$. 
같다. 색도 중 $\mathrm{L}$ 값은 대조군, 가시파래 $1 \%$ 첨가군, $3 \%$ 첨가 군, $5 \%$ 첨가군이 각각 $77.5,67.9,62.7,58.1$ 로 유의적으로 감소하였고, a값도 각각 $3.35,0.19,-2.36,-3.69$ 로 유의적으 로 감소한 반면, $\mathrm{b}$ 값은 각각 $19.3,20.9,21.4,22.1$ 로 유의적 으로 증가하였다 $(\mathrm{p}<0.05)$. 이는 가시파래 모닝빵 $(\mathrm{Kim}$ 등, 2019b), 가시파래 마카롱(Baek 등, 2019), 가시파래 대두 스 프레드(Song과 Kim, 2020)와 경향이 같았다. 짙은 녹색을 띠 는 가시파래 첨가량이 증가할수록 시료의 색이 점차 어두워 짐에 따라 $\mathrm{L}$ 값이 감소되는 것으로 생각되고, $-\mathrm{a}$ 값은 녹색을 나타내기 때문에 가시파래를 첨가할수록 -a값을 향한 것으로 생각된다. 쌀가루는 고온에서 색이 누렇게 변하는 특성(Lee 등, 2003)이 있고, puffed rice가 옅은 노란색을 띠어 b값이 증가한 것으로 생각된다.

\section{피코시아닌 및 클로로필 함량}

가시파래 첨가 크리스피 쌀과자의 피코시아닌 및 클로로 필 결과는 Table 3 과 같다. c-피코시아닌은 대조군, 가시파래 $1 \%$ 첨가군, $3 \%$ 첨가군, $5 \%$ 첨가군이 각각 $4.69 \mu \mathrm{g} / \mathrm{g}, 6.47$ $\mu \mathrm{g} / \mathrm{g}, 6.90 \mu \mathrm{g} / \mathrm{g}, 7.57 \mu \mathrm{g} / \mathrm{g}$ 이고, 알로피코시아닌은 각각 7.18 $\mu \mathrm{g} / \mathrm{g}, 10.22 \mu \mathrm{g} / \mathrm{g}, 11.24 \mu \mathrm{g} / \mathrm{g}, 11.63 \mu \mathrm{g} / \mathrm{g}$ 로 가시파래 첨가량 에 따라 유의적으로 증가함을 보였다( $p<0.05)$. 피코시아닌은 해조류에 함유된 청색 색소로 광합성과 영양소 공급 이외에 도 담즙색소처럼 지방 소화를 돕는다고 알려져 있다. 또한, 색소로써 항산화 효과를 갖는데, 항산화 활성은 플라보노이 드와 페놀성 화합물과도 유사하다고 보고된다(Kim 등, 2010; Spirulina Research Society, 2005).

클로로필a는 대조군, 가시파래 $1 \%$ 첨가군, $3 \%$ 첨가군, $5 \%$ 첨가군이 각각 $0.46 \mu \mathrm{g} / \mathrm{g}, 0.69 \mu \mathrm{g} / \mathrm{g}, 1.17 \mu \mathrm{g} / \mathrm{g}, 1.74 \mu \mathrm{g} / \mathrm{g}$ 이 고, 클로로필b는 $0.81 \mu \mathrm{g} / \mathrm{g}, 0.91 \mu \mathrm{g} / \mathrm{g}, 1.15 \mu \mathrm{g} / \mathrm{g}, 1.48 \mu \mathrm{g} / \mathrm{g}$ 로 가시파래 첨가량이 증가함에 따라 유의적으로 증가하였다 $(\mathrm{p}<0.05)$. 클로로필은 식물과 해조류에 함유된 녹색 색소로 엽록소라고도 하며, 색소로써 항산화 활성이 높다(Song 등, 2001; Yoo 등, 2013). 다만 Nguyen 등(2018)에서 클로로필
은 온도가 높아짐에 따라 점차 색소 성분이 파괴되고 분해되 는 것으로 보고됨에 따라 제조 시, 고온에서 오랫동안 조리하 지 않는 것이 좋을 것으로 생각된다.

김이나 가시파래를 첨가함으로써 피코시아닌 및 클로로필 함량이 증가한 식품으로는 가시파래 설기떡(Kim 등, 2019d), 김 마지팬(Kim 등, 2020) 연구 등이 있어 해조류를 식품에 활용함으로써 지방 소화나 항산화 효과 등에 효과가 있을 것 으로 생각된다.

\section{플라보노이드 함량}

플라보노이드는 대표적인 폴리페놀 화합물의 일종으로 플 라본을 기본구조로 가진 담황색의 수용성 색소로써 천연물질 에 존재하며, 항종양, 항염증, 항산화 등의 생리활성을 가지 고 있다(Hwang, 2018; Lee 등, 2014). 항산화 능력은 산화를 촉진하는 구리나 철과의 결합능력이 좋아 활성을 띠게 된다 (Kang 등, 2015).

가시파래 첨가 크리스피 쌀과자의 플라보노이드 함량 결 과는 Fig. 1 과 같다. 대조군, 가시파래 $1 \%$ 첨가군, $3 \%$ 첨가 군, $5 \%$ 첨가군은 각각 $0.15 \mathrm{mg} \mathrm{NAE} / \mathrm{g}, 0.21 \mathrm{mg} \mathrm{NAE} / \mathrm{g}$, $0.24 \mathrm{mg} \mathrm{NAE} / \mathrm{g}, 0.29 \mathrm{mg} \mathrm{NAE} / \mathrm{g}$ 으로 가시파래 첨가량이 증 가함에 따라 플라보노이드 함량 또한 유의적으로 증가하였다 $(\mathrm{p}<0.05)$. 가시파래의 플라보노이드 함량은 $15.32 \mathrm{mg} \mathrm{NAE} / \mathrm{g}$ 으로(Baek과 Kim, 2019), 채소 중 우엉이나 붉은 고추와 비 슷한 수치라고 하였다(Kwak 등, 2005). 가시파래 모닝빵 (Kim 등, 2019b)과 가시파래 곤약젤리(Kim 등, 2019c), 가시 파래 설기떡(Kim 등, 2019d), 가시파래 대두 스프레드(Song 과 Kim, 2020) 등 가시파래를 첨가한 식품 연구에서도 플라 보노이드 함량이 증가하는 경향을 보이며, 본 연구와 경향이 같았다. 따라서 가시파래 $5 \%$ 첨가군의 항산화 활성이 가장 클 것으로 사료된다.

\section{총페놀성 화합물 함량}

페놀성 화합물은 자유 라디칼을 환원시키는 물질로서 항

Table 3. Phycocyanin and chlorophyll contents of rice crispy cereal added with Enteromorpha prolifera

\begin{tabular}{cccccc}
\hline & & Control $^{1)}$ & EPC $^{2)} 1$ & EPC 3 & EPC 5 \\
\hline \multirow{2}{*}{ Phycocyanin $(\mu \mathrm{g} / \mathrm{g})$} & c-Phycocyanin & $\left.4.69 \pm 0.05^{\mathrm{c} 3}\right)$ & $6.47 \pm 0.25^{\mathrm{b}}$ & $6.90 \pm 0.40^{\mathrm{b}}$ & $7.57 \pm 0.29^{\mathrm{a}}$ \\
& Allophycocyanin & $7.18 \pm 0.11^{\mathrm{c}}$ & $10.22 \pm 0.39^{\mathrm{b}}$ & $11.24 \pm 0.84^{\mathrm{a}}$ & $11.63 \pm 0.42^{\mathrm{a}}$ \\
\hline \multirow{2}{*}{ Chlorophyll $(\mu \mathrm{g} / \mathrm{g})$} & Chlorophyll a & $0.46 \pm 0.01^{\mathrm{d}}$ & $0.69 \pm 0.01^{\mathrm{c}}$ & $1.17 \pm 0.01^{\mathrm{b}}$ & $1.74 \pm 0.05^{\mathrm{a}}$ \\
& Chlorophyll b & $0.81 \pm 0.00^{\mathrm{d}}$ & $0.91 \pm 0.01^{\mathrm{c}}$ & $1.15 \pm 0.02^{\mathrm{b}}$ & $1.48 \pm 0.04^{\mathrm{a}}$ \\
\hline
\end{tabular}

\footnotetext{
${ }^{1)}$ Control, rice crispy cereal without E. prolifera; EPC 1, $1 \%$ E. prolifera rice crispy cereal; EPC 3, 3\% E. prolifera rice crispy cereal; EPC 5, $5 \%$ E. prolifera rice crispy cereal.

${ }^{2)} \mathrm{EPC}$, Enteromorpha prolifera rice crispy cereal.

${ }^{3)}$ Mean \pm SD $(n=3)$ within each row followed by different letters $\left({ }^{a-d}\right)$ are significantly different $(\mathrm{p}<0.05)$.
} 


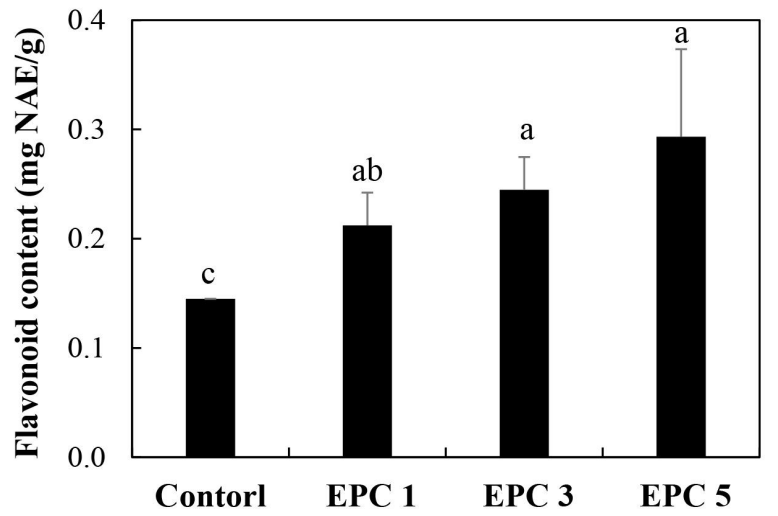

Fig. 1. Flavonoid content of rice crispy cereal added with Enteromorpha prolifera.

Control, rice crispy cereal without E. prolifera; EPC 1, 1\% E. prolifera rice crispy cereal; EPC 3, 3\% E. prolifera rice crispy cereal; EPC 5 , $5 \%$ E. prolifera rice crispy cereal.

EPC, Enteromorpha prolifera rice crispy cereal

Mean \pm SD $(n=3)$ within each bars by different letters $\left({ }^{\mathrm{a}-\mathrm{c}}\right)$ are significantly different $(\mathrm{p}<0.05)$

균 및 항염의 생리활성을 갖고 강한 항산화 활성을 가지고 있는 물질로 연구되어 왔다(Baek과 Kim, 2019). 또한 총페놀 성 화합물은 지질 과산화 억제율과 DPPH 라디칼 소거능과 상관관계를 가지고 있다고 연구되었다(Kwak 등, 2005).

가시파래 첨가 크리스피 쌀과자의 총페놀성 화합물 함량 결과는 Fig. 2 와 같다. 대조군, 가시파래 $1 \%$ 첨가군, $3 \%$ 첨가 군, $5 \%$ 첨가군은 각각 $1.14 \mathrm{mg} \mathrm{TAE} / \mathrm{g}, 1.40 \mathrm{mg} \mathrm{TAE} / \mathrm{g}$, $1.56 \mathrm{mg} \mathrm{TAE} / \mathrm{g}, 1.64 \mathrm{mg} \mathrm{TAE} / \mathrm{g}$ 으로 가시파래 첨가량에 따

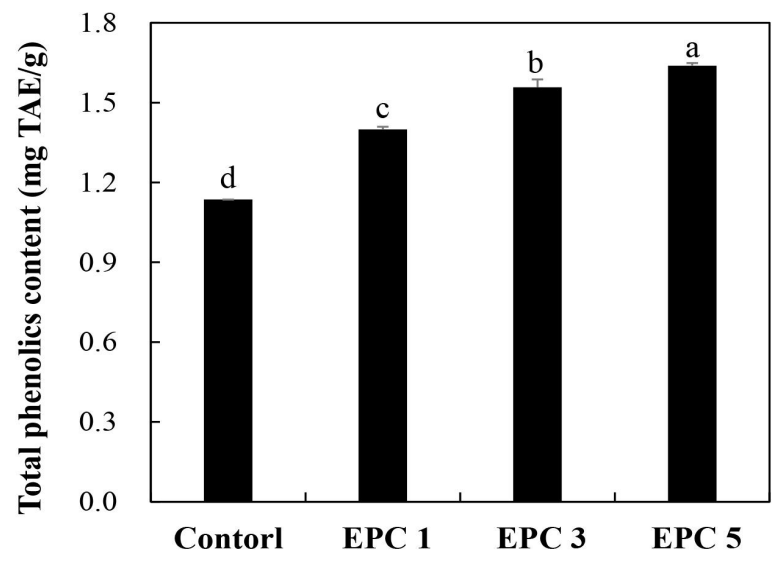

Fig. 2. Total phenolics content of rice crispy cereal added with Enteromorpha prolifera.

Control, rice crispy cereal without E. prolifera; EPC 1, 1\% E. prolifera rice crispy cereal; EPC 3, 3\% E. prolifera rice crispy cereal; EPC 5, $5 \%$ E. prolifera rice crispy cereal.

$\operatorname{Mean} \pm$ SD $(n=3)$ within each bars followed by different letters $\left.{ }^{(a-d}\right)$ are significantly different $(\mathrm{p}<0.05)$.
라 유의적으로 증가하였다( $<0.05) . B a e k$ 과 $\operatorname{Kim}(2019)$ 에서 가시파래의 총페놀성 화합물 함량은 $40.94 \mathrm{mg} \mathrm{TAE} / \mathrm{g}$ 으로 매우 높게 측정되었기에 가시파래를 첨가한 크리스피 쌀과자 의 총페놀성 화합물 함량이 높게 나타나는 것으로 사료된다. 가시파래 첨가량이 가장 많은 가시파래 $5 \%$ 첨가군에서 항산 화 활성이 클 것으로 사료된다. 가시파래 마카롱(Baek 등, 2019), 김 마지팬(Kim 등, 2020) 등의 연구에서도 해조류 함 량이 증가함에 따라 총페놀성 화합물 함량이 증가하는 결과 를 통해 가시파래를 크리스피와 같은 디저트류에 첨가함으로 써 항산화 효과를 기대할 수 있을 것으로 생각된다.

\section{DPPH 라디칼 소거능}

가시파래 첨가 크리스피 쌀과자의 DPPH 라디칼 소거능을 $\mathrm{IC}_{50}$ 값으로 나타낸 결과는 Fig. 3과 같다. 대조군, 가시파래 $1 \%$ 첨가군, $3 \%$ 첨가군, $5 \%$ 첨가군은 각각 $801.3 \mathrm{mg} / \mathrm{mL}$, $779.1 \mathrm{mg} / \mathrm{mL}, 647.9 \mathrm{mg} / \mathrm{mL}, 471.3 \mathrm{mg} / \mathrm{mL}$ 로 $\mathrm{IC}_{50}$ 값은 가시 파래 첨가량이 증가함에 따라 유의적으로 감소하였다 $(\mathrm{p}<0.05) . \mathrm{DPPH}$ 는 자유 라디칼을 가지는데, $\mathrm{IC}_{50}$ 값은 자유 라디칼을 $50 \%$ 소거하는 데 필요한 농도이므로 그 값이 작을 수록 자유 라디칼 제거 효과가 큰, 즉 항산화 활성이 높다는 것을 의미한다. 따라서 $\mathrm{IC}_{50}$ 값이 작은 가시파래 $5 \%$ 첨가군의 항산화 활성이 가장 큰 것으로 사료된다. 그러나 Kwak 등 (2005)에서 파래의 DPPH 라디칼 소거능은 파래 시료의 농도 에 따라 다르게 분석된다고 하였다. 파래 시료 농도가 1,000 $\mu \mathrm{g} / \mathrm{mL}$ 이하일 때는 다시마나 김, 톳, 미역보다 소거능이 우 수했으나, 파래 시료 농도가 $2,500 \mu \mathrm{g} / \mathrm{mL}$ 일 때는 다시마, 김 의 소거능이 더 높게 나타나며 차이를 보였다. 이는 추출에도

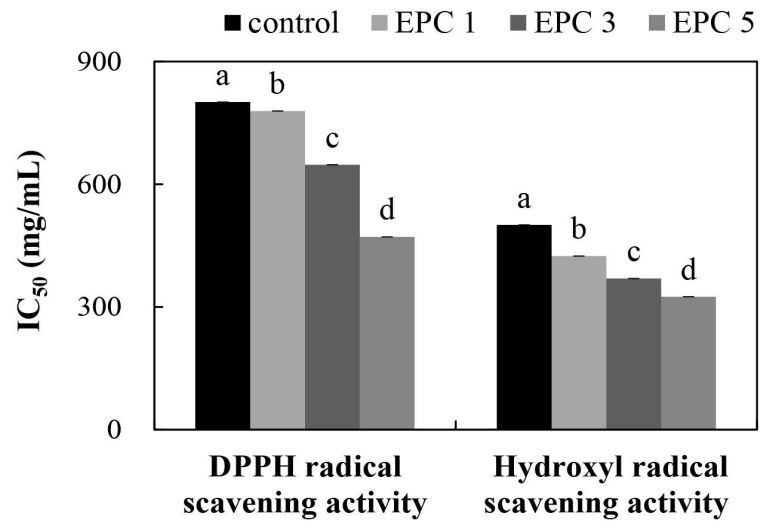

Fig. 3. DPPH and hydroxyl radical scavenging activities of rice crispy cereal added with Enteromorpha prolifera.

Control, rice crispy cereal without E. prolifera; EPC 1, 1\% E. prolifera rice crispy cereal; EPC 3, 3\% E. prolifera rice crispy cereal; EPC 5, $5 \%$ E. prolifera rice crispy cereal.

Mean \pm SD $(n=3)$ within each bars followed by different letters $\left(^{\text {a-d }}\right)$ are significantly different $(\mathrm{p}<0.05)$. 
최적의 시료 농도가 존재한다는 것을 의미한다. 즉, 시료의 농도나 추출물질 등에 따라 항산화능 수치가 다르게 도출될 수 있다는 것을 의미하며, 항산화 활성을 최적으로 구하기 위 해서는 시료 농도와 DPPH 용액의 농도 비가 중요할 것으로 생각된다. Baek과 Kim(2019)에서 가시파래의 DPPH 라디칼 소거능은 $114.9 \mathrm{mg} / \mathrm{mL}$ 로 도출되어 가시파래 분말 자체의 항 산화성은 높다고 생각되며, 가시파래가 플라보노이드나 페놀 성 화합물 등의 항산화 성분을 많이 함유하고 있어서 $\mathrm{DPPH}$ 라디칼 소거능이 높게 나타난 것으로 보인다.

\section{Hydroxyl 라디칼 소거능}

가시파래 첨가 크리스피 쌀과자의 hydroxyl 라디칼 소거능 을 $\mathrm{IC}_{50}$ 값으로 나타낸 결과는 Fig. 3 과 같다. 대조군, 가시파래 $1 \%$ 첨가군, $3 \%$ 첨가군, $5 \%$ 첨가군은 각각 $500.9 \mathrm{mg} / \mathrm{mL}$, $424.5 \mathrm{mg} / \mathrm{mL}, 369.8 \mathrm{mg} / \mathrm{mL}, 325.0 \mathrm{mg} / \mathrm{mL}$ 로 가시파래 첨가 량이 증가함에 따라 $\mathrm{IC}_{50}$ 값이 유의적으로 감소하였다 $(\mathrm{p}<0.05)$. Hydroxyl 라디칼은 자유 라디칼 중 반감기가 짧아 가장 독성 이 크다고 알려진 활성산소종으로, 불안정하며 큰 반응성으 로 인해 DNA를 손상시키고, 세포를 변화시켜 노화와 암까지 유발하는 물질이다(Kim 등, 2019c; Min 등, 2008). $\mathrm{IC}_{50}$ 값이 낮을수록 라디칼 소거능이 좋으므로 항산화 활성은 가시파래 $5 \%$ 첨가군에서 가장 크다는 것을 알 수 있다. 가시파래는 항 산화 활성이 높은 천연 항산화제이기 때문에 이를 식품에 첨 가할 경우, 합성 항산화제에서 문제가 되는 발암과 독성에 대 해 안전하면서도 식품 자체의 항산화성을 높여주는 역할을 함으로써 식품을 섭취하는 소비자로 하여금 좋은 효과를 가 질 것으로 생각된다.

\section{관능 특성}

가시파래 첨가 크리스피 쌀과자의 강도검사 결과는 Table 4 와 같다. 외관 색, 가시파래 향, 가시파래 맛, 전반적인 수용도 는 가시파래 $5 \%$ 첨가군에서 유의적으로 가장 높았고 $(\mathrm{p}<0.05)$,
비린향은 유의적인 차이를 보이지 않았다 $(\mathrm{p}>0.05)$. 가시파래 를 첨가함에 따라 외관 색이 진해진 것은 색도의 $\mathrm{L}$ 값 결과 (Table 2)에 의한 평가 결과라고 생각되고, 가시파래 향과 맛 은 가시파래 첨가량에 따라 비례하여 향과 맛이 강해진 것으 로 생각된다. 비린향은 가시파래 $5 \%$ 첨가군에서 가장 높았 지만, 강도는 1.8 점으로 거의 없는 수준으로 나타났다. 이는 버터와 마시멜로우 등의 재료의 맛에 의해 가시파래의 비린 향이 가려진 것으로 생각된다. 따라서 $5 \%$ 첨가군에서 가시 파래의 향과 맛은 강했지만, 이는 시료에 비린내가 아닌 풍미 로써 작용할 것으로 생각된다. 전반적인 수용도는 가시파래 $5 \%$ 첨가군에서 가장 높은 값을 보였는데 $(\mathrm{p}<0.05)$, 가시파래 의 향과 맛의 강도가 높았지만, 비린향이 적어 전체적으로 가 시파래가 다른 재료와 맛과 향에서 적절한 조화를 보였기 때 문이라고 생각된다.

가시파래를 첨가한 크리스피 쌀과자는 대조군과 비교하여 향, 맛, 전반적인 수용도가 품질 특성 결과와 상응하고, 조화 를 보이는 것으로 보아 기능성 성분을 첨가한 크리스피 쌀과 자의 식품 개발이 기대되며, 더 나아가 가시파래를 활용한 식 품의 개발에도 도움이 될 것으로 생각된다.

\section{요 약}

본 연구는 크리스피 쌀과자에 기능성 식품인 가시파래를 $1 \%, 3 \%, 5 \%$ 첨가하여 제조하고, 건강기능적인 특성을 알아 보기 위하여 품질 특성과 항산화성을 측정하였다. 가시파래 크리스피 쌀과자의 환원당은 가시파래를 첨가함에 따라 값이 감소하였다. 색도는 가시파래를 첨가할수록 $\mathrm{L}$ 값 및 $\mathrm{a}$ 값은 점 차 감소하였고, $\mathrm{b}$ 값은 증가하였다. 항산화 활성를 가지는 색 소인 피코시아닌 및 클로로필은 가시파래를 첨가할수록 증가 하였다. 항산화 성분인 플라보노이드 및 페놀성 화합물 함량 은 가시파래에 풍부하여 가시파래 $5 \%$ 첨가군에서 가장 높게 나타났고, 항산화 활성을 나타내는 DPPH 및 hydroxyl 라디

Table 4. Mean scores of intensity test of rice crispy cereal added with Enteromorpha prolifera

\begin{tabular}{cllll}
\hline & Control $^{\mathrm{l})}$ & $\mathrm{EPC}^{2)} 1$ & EPC 3 & EPC 5 \\
\hline Exterior color & $1.4 \pm 0.9^{\mathrm{c} 3)}$ & $3.2 \pm 0.4^{\mathrm{b}}$ & $4.0 \pm 0.7^{\mathrm{ab}}$ & $4.6 \pm 0.5^{\mathrm{a}}$ \\
Fishy smell & $1.0 \pm 0.0^{\mathrm{a}}$ & $1.2 \pm 0.4^{\mathrm{a}}$ & $1.4 \pm 0.5^{\mathrm{a}}$ & $5.6 \pm 0.9^{\mathrm{a}}$ \\
Flavor of E. prolifea & $1.0 \pm 0.0^{\mathrm{c}}$ & $4.8 \pm 0.4^{\mathrm{b}}$ & $5.6 \pm 0.5^{\mathrm{a}}$ & $6.2 \pm 0.8^{\mathrm{a}}$ \\
Taste of E. prolifea & $1.0 \pm 0.0^{\mathrm{c}}$ & $3.2 \pm 0.8^{\mathrm{b}}$ & $4.4 \pm 0.5^{\mathrm{a}}$ & $4.8 \pm 0.4^{\mathrm{a}}$ \\
Overall acceptability & $4.8 \pm 0.4^{\mathrm{c}}$ & $5.2 \pm 0.4^{\mathrm{c}}$ & $5.8 \pm 0.4^{\mathrm{b}}$ & $7.0 \pm 0.0^{\mathrm{a}}$ \\
\hline
\end{tabular}

\footnotetext{
${ }^{1)}$ Control, rice crispy cereal without E. prolifera; EPC 1, 1\% E. prolifera rice crispy cereal; EPC 3, 3\% E. prolifera rice crispy cereal; EPC 5, $5 \%$ E. prolifera rice crispy cereal.

${ }^{2}$ EPC, Enteromorpha prolifera rice crispy cereal.

${ }^{3)}$ Mean \pm SD $(n=8)$ within each row followed by different letters $\left({ }^{a-c}\right)$ are significantly different $(\mathrm{p}<0.05)$.
} 
칼 소거능 또한 가시파래 $5 \%$ 첨가군에서 항산화 활성이 가 장 높게 나타났는데, 가시파래에 함유된 항산화 물질에 의한 것으로 생각된다. 전반적인 수용도는 $5 \%$ 첨가군에서 가장 높게 나타났는데, 이는 가시파래 맛과 향이 강하지만, 버터나 마시멜로우로 인해 비린향이 가려진 결과라고 생각된다. Puffed rice는 감미 성분과 지방 성분의 함량이 높은데, 영양 성분과 생리활성물질이 풍부한 가시파래를 첨가하여 크리스 피 쌀과자를 제조함으로써 영양적인 면을 개선하고, 가시파 래를 활용한 식품을 개발하는 데 기초자료로 활용될 것으로 생각된다.

\section{감사의 글}

이 논문은 2019년 해양수산부 재원으로 해양수산과학기술 진흥원의 지원을 받아 수행된 연구임(충청 씨그랜트).

\section{Conflict of interests}

The authors declare no potential conflict of interest.

\section{ORCID}

$\begin{array}{ll}\text { Da Hee Kim } & \text { https://orcid.org/0000-0003-4149-5014 } \\ \text { Mee Ree Kim } & \text { https://orcid.org/0000-0003-3813-1447 }\end{array}$

\section{References}

Aida TM, Tajima K, Watanabe M, Saito Y, Kuroda K, Nonaka T, Hattori H, Smith Jr RL, Arai K. Reactions of D-fructose in water at temperatures up to $400^{\circ} \mathrm{C}$ and pressures up to $100 \mathrm{MPa}$. J Supercrit Fluids, 42, 110119 (2007)

AOAC. Official Methods of Analysis. 13th ed, Association of Official Analytical Chemists, Arlington, VA, USA (1990)

Baek SY, Kim MR. Comparison of quality characteristic and antioxidant activity of Enteromorpha prolifera from Seosan and Muan in Korea. J Korean Soc Food Sci Nutr, 48, 1070-1078 (2019)

Baek SY, Sha XT, Hwang MH, Kim MR. Physicochemical properties and antioxidant activities of macarons added with Enteromorpha prolifera powder. J Korean Soc Food Sci Nutr, 48, 1373-1382 (2019)

Blois MS. Antioxidant determinations by the use of a stable free radical. Nature, 181, 1199-1200 (1958)

Davis WB. Determination of flavonones in citrus fruits. Anal Chem, 19, 476-478 (1947)

Goldstein A, Tachibana S, Lowney LI, Hunkapiller M, Hood L. Dynorphin-(1-13), an extraordinarily potent opioid peptide. Proc Natl Acad Sci USA, 76, 6666-6670 (1979)

Guk SY, Han JH. Development Strategy of Rice Processing Industry. Korea Rural Economic Institute Research report R611-2, p 5 (2010)

Han SH, Kum JS, Lee HY, Park JD. Development and quality properties of cereal bars. Korean J Food Preserv, 12, 235-240 (2005)

Hwang WS. Synthesis of flavonoid aglycones and confirmation of tyrosinase inhibitory effect. MS Thesis, Kangwon National University, Korea, p 1 (2018)

Joo SY, Choi HY. Quality characteristics of cabbage rice nutritional bars made with varying ratios of cabbage powder. Korean J Food Cook Sci, 32, 441-448 (2016)

Kang IJ, Kang MH, Kim MS, Park SS, Byun EG, You SH, Yook HS, Lee KH, Lee MK, Le YT, Lee OH, Lee JS, Lim SS, Lim JY, Jeon WJ, Chung SJ, Chung YH, Chung HJ. Food Chemistry Guideline. Life Science Publishing Co, Seoul, Korea, p 219 (2015)

Kim DH, Kim SJ, Kim MR. Physicochemical properties and antioxidant activities of allulose konjac jelly added with Enteromorpha prolifera. J Korean Soc Food Sci Nutr, 48, 967-976 (2019c)

Kim DH, Baek SY, Kim SJ, Kim MR. Physicochemical properties and antioxidant activities of Sulgidduk added with Enteromorpha prolifera. J Korean Soc Food Sci Nutr, 48, 1090-1097 (2019d)

Kim DH, Kim SJ, Park MA, Kim MR. Physicochemical properties and antioxidant activities of marzipan chocolate with added dried laver. J Korean Soc Food Sci Nutr, 49, 149-157 (2020)

Kim HJ, Shim EK, Kim HR, Kim MR. Antioxidant activities of riceyeotgangjung with added spirulina powder. Korean J Food Culture, 25, 795-800 (2010)

Kim JK, Park JH, Jang EH, Surayot UP, You SG. Immunomodulatory effect of sulfated polysaccharides and its low molecular form isolated from Enteromorpha prolifera in BALB/c mice. J Chitin Chitosan, 21, 82-88 (2016)

Kim MR, Choi CU, Baek SY. Healthy Recipe of Gamtae from the Yellow Sea. Chungnam National University 
Publishing Culture Center, Daejeon, Korea, p 8-85 (2019a)

Kim SJ, Baek SY, Kim DH, Kim MR. Physicochemical properties and antioxidant activities of morning bread added with Enteromorpha prolifera. J Korean Soc Food Sci Nutr, 48, 1244-1252 (2019b)

Korean Statistical Information Service (KOSIS). 2018 Grain Consumption Survey Results. http://kostat.go.kr/portal/k orea/kor_nw/1/4/8/index.board?bmode $=$ read $\& b S e q=\& a S$ eq $=372958 \&$ pageNo $=1 \&$ row $N u m=10 \&$ navCount $=10 \& \mathrm{c}$ urrPg $=\&$ searchInfo $=\&$ sTarget $=$ title $\&$ T Txt $=($ accessed Ma y 2020)

Kwak CS, Kim SA, Lee MS. The correlation of antioxidative effects of 5 Korean common edible seaweeds and total polyphenol content. J Korean Soc Food Sci Nutr, 34, 1143-1150 (2005)

Lee BJ. Development of functional food using fermented marine organism. Food Industry and Nutrition, 18, 8-12 (2013)

Lee GC, Kim SJ, Koh BK. Effect of roasting condition on the physicochemical properties of rice flour and the quality characteristics fo Tarakjuk. Korean J Food Sci Technol, 35, 905-913 (2003)

Lee JA. Quality characteristics of rice cereal bars containing different levels of mulberry leaf (Morus alba Linne) powder. Culi Sci Hosp Res, 25, 119-126 (2019)

Lee JH, Kim MR, Min HS, Lee YE, Song ES, Gwon SJ, Kim MJ, Song HN. Food and Cook Principle. Kyomunsa Publishing Co, Seoul, Korea, p 160 (2014)

Li B, Liu S, Xing R, Li K, Li R, Qin Y, Wang X, Wei Z, Li P. Degradation of sulfated polysaccharides from Enteromorpha prolifera and their antioxidant activities. Carbohydr Polym, 92, 1991-1996 (2013)

Li D, Chen L, Zhao J, Zhang X, Wang Q, Wang H, Ye N. Evaluation of the pyrolytic and kinetic characteristics of Enteromorpha prolifera as a source of renewable biofuel from the yellow sea of China. Chem Eng Res Des, 88, 647-652 (2010)

Liao MJ, Hao ZK, Shang DR, Jiang Y, Chen GP, Wang YG. Nutrition components analysis of Enteromorpha prolifera and its preliminary study on feeding Apostichopus japonicus. Fish Modern, 38, 32-36 (2011)

Lin G, Liu X, Yan X, Liu D, Yang C, Liu B, Huang Y, Zhao C. Role of green macroalgae Enteromorpha prolifera polyphenols in the modulation of gene expression and intestinal microflora profiles in type 2 diabetic mice. Int J Mol Sci, 20, 25 (2019)

Lin W, Wang W, Liao D, Chen D, Zhu P, Cai G, Kiyoshi A. Polysaccharides from Enteromorpha prolifera improve glucose metabolism in diabetic rats. J Diabetes Reas, 2015, 675201 (2015)

Mao WJ, Fang F, Li HY, Qi XH, Sun HH, Chen Y, Guo SD. Heparinoid-active two sulfated polysaccharides isolated from marine green algae Monostroma nitidum. Carbohydr Polym, 74, 834-839 (2008)

Min OJ, Kim MS, Kwak BH, Rhyu DY. Peroxynitrite and hydroxyl radical scavenging activity of medicinal plants. Korean J Plant Res, 21, 254-259 (2008)

Nguyen TT, Choi YJ, Nguyen THP, Neri TA, Choi BD. Changes in nutrient and pigment contents of laver Pyropia yezoensis based on heating process and storage. Korean J Fish Aquat Sci, 51, 221-229 (2018)

Park SJ, Choi YB, Ko JR, Rha YA, Lee HY. Quality evaluation of the nutritional cereal bar with citrus fruit extract. Korean J Culi Res, 20, 245-253 (2014)

Rye HS, Choi HY, Joo SY. Quality characteristics of rice nutritional bar added with aronia byproducts powder. Korean J Food Nutr, 28, 947-955 (2015)

Shim EK, Kim HJ, Kim HR, Kim MR. Quality characteristics of riceyeotgangjung with added spirulina powder. J East Asian Soc Diet Life, 20, 888-895 (2010)

Singleton VL, Orthofer R, Lamuela-Raventos RM. Analysis of total phenols and other oxidation substrates and antioxidants by means of Folin-Ciocalteu reagent. Methods Enzymol, 299, 152-178 (1999)

Song ES, Jeon YS, Choi HS. Antioxidative effect of chlorophylls and carotenoids in mustard leaf kimchi activity. J Korean Soc Food Sci Nutr, 30, 421-425 (2001)

Song MJ, Kim MR. Quality characteristics and antioxidant activities of soybean spread with Enteromorpha prolifera powder. J Korean Soc Food Sci Nutr, 49, 262-269 (2020)

Spirulina Research Society. Full-Food Spirulina. Hangaram Seowon Publishing Co, Seoul, Korea, p 39-40 (2005)

Tie J, Yu JH, Ryu GH. Effect of moisture content and temperature on physical properties of instant puffed rice snacks. J Korean Soc Food Sci Nutr, 41, 846-852 (2012)

Yoo HJ, Ahn CS, Naratuya L. Extractions of chlorophyll from spinach and mate powders and their dyeability on fabrics. J Korean Soc Cloth Textil, 37, 413-423 (2013) 